\title{
North Atlantic white shrimp Litopenaeus setiferus (Decapoda: Penaeidae) as an aquaculture target species for farming: a review
}

\author{
Manuel Valenzuela-Jiménez ${ }^{1,2}$, Claudia Durruty-Lagunes ${ }^{1}$, Gerard Cuzon ${ }^{1}$ \\ Wilson Wasielesky $\mathrm{Jr}^{2}{ }^{2} \&$ Gabriela Gaxiola ${ }^{1}$ \\ ${ }^{1}$ Unidad Multidisciplinaria de Docencia e Investigación, Facultad de Ciencias \\ Universidad Nacional Autónoma de México, Sisal, Yucatán, México \\ ${ }^{2}$ Estação Marinha de Aquacultura, Instituto de Oceanografia \\ Universidade Federal do Rio Grande (FURG), Rio Grande, Brasil \\ Corresponding author: Gabriela Gaxiola (mggc@ ciencias.unam.mx)
}

\begin{abstract}
Litopenaeus setiferus has been described as an economically important native species ranging from the north Atlantic along the coast of the Gulf of Mexico to Florida. Its reproduction has been studied in captivity, as well as some aspects of its nutritional physiology, diseases and adaptation to various environments, including nurseries. In terms of growth, L. setiferus has been compared with $L$. vannamei for its performance in ponds. As a native species, L. setiferus benefits local fisheries and is also used as a bait shrimp for recreational activity. The present review covers background information and recent advances in research and development efforts to determine its potential both for aquaculture in ponds and intensive biofloc systems (BFT), as well as for the stocking of fishing grounds. The collective research advances for this species presented in this review could help to sustain various strategies, including highly intensive techniques, to rehabilitate L. setiferus in connection with potential institutes.
\end{abstract}

Keywords: Litopenaeus setiferus; native species; reproduction; larval rearing; farming; biofloc system; diseases

The northern white shrimp Litopenaeus setiferus (Linnaeus, 1767) is one of the species with the highest commercial value in the Atlantic, but the decline in its natural populations places this species in an ecologically sensitive situation, not only for production but also for conservation. L. setiferus is caught from North Carolina to Florida in the Gulf of Mexico. Both the United States and Mexico share the eastern coast from New Jersey to Florida and from Tamaulipas to Campeche. Its distribution is at approximately 2 to 90 $\mathrm{m}$ depth in muddy bottoms, with organic matter, sand and clay. Juveniles and adults can be found in estuarine areas (FAO, 1980).

Thus, L. setiferus is a euryhaline species, which can grow in various salinities either at sea or in low-salinity brackish water. In the coastal zone of the Gulf of Mexico, mangrove destruction has decreased areas essential to the first phases of its life cycle. Oil platforms and thermoelectric plants, as well as tourism, are also sources of estuarine habitat alteration and loss of marine habitat as well. Ports, dredging, fuel exploration, oil spills and the introduction of exotic flora and fauna have contributed to the anthropogenic impacts of their natural populations. Such impacts have increased the effects of natural events (e.g., red tides, hurricanes, tropical storms, upwellings and northern and southern winds, including El Niño, La Niña) and have contributed to the decline in fishery resources (ArenasFuentes \& Jiménez-Badillo, 2004).

Over the last 10 years, exotic species, such as Litopenaeus vannamei (king prawn; Wakida-Kusunoki et al., 2011) and Penaeus monodon (giant tiger prawn; Fuller et al., 2014) were reported in the Gulf of Mexico, although both species present but not settled along the Mexican coast. The low frequency of specimens found in lagoons and coastal areas, during a monitoring pro-

Corresponding editor: Sandra Bravo 
gram for artisanal and industrial fisheries, indicated an absence of well-established populations of giant tiger prawn or white shrimp. Specimens examined did not carry eggs; additional sampling and long-term monitoring are needed to assess the potential impact on native species (Wakida-Kusunoki et al., 2013).

Given the current situation for natural populations of $L$. setiferus, aquaculture remains an option for conservation. Shrimp farms are widely based on domesticated exotic species from many regions and can enhance the sustainability of native species (Gaxiola $e t$ $a l ., 2008)$. Therefore, more studies are needed to elucidate methods to nurture and produce $L$. setiferus.

\section{Shrimp fisheries}

Historically, fishing in the Gulf of Mexico has been a substantial economic activity in this region. Commercial fishing also can indirectly generate jobs in processing and side services, which are common both in Mexican and U.S. waters, with many industries including $L$. setiferus (Gracia, 2004).

The life cycle of white shrimp starts on the continental shelf between 4 and $40 \mathrm{~m}$ depth (Williams, 1984), where fertilized eggs are derived from currents and 12 to $14 \mathrm{~h}$ later nauplii emerge and are sustained on its reserves. At between 12 to 15 days of age, planktonic larvae move to the coast in search of refuge areas in lagoons or estuaries until they reach the post-larvae stage (Pls), when they graze on submerged vegetation. In these nurseries, they spend 7-9 months before migrating back to the sea as adults (Renaud, 1986; Zein-Eldin \& Renaud, 1986; Chow et al., 1993; Misamore \& Browdy, 1996; Rosas et al., 1999, 2004). L. setiferus has been extensively studied as a potential resource for fisheries, as well as its relationship with populations, recruitment and overfishing (Gracia, 1991, 1996, 1999). Gracia \& Soto (1990) described one nursery, a refuge and grazing zone for Pls and preadults, in Laguna de Términos (southern Gulf of Mexico).

Some studies on larvae in coastal lagoons have included an analysis of currents and migration of larvae at Carmen and Laguna Machona (Gierloff-Emdem, 1977; Flores-Coto et al., 2010). Models and simulation programs have been developed (Diop et al., 2007) to estimate significant relationships among the abundance of the initial life stages, temperature and salinity. At the same time, loss of wetlands and high discharge of rivers have been related to low abundance. Biological factors, such as the number of juveniles in early life stages, can be used to predict later abundance, with a similar relationship between late juveniles and adults caught per unit of effort.
Baker et al. (2014) presented a model to determine the effects of juvenile growth and mortality on natural populations and determined that modest changes could have a greater impact on the size of fishery stocks than mortality in previous decades. It was suggested that variability in juvenile survival could be a strong driver of adult population size. Processes that regulate growth and mortality need to be understood for effective management of coastal nurseries and stocks established in coastal lagoons regulate both parameters for juveniles (Minello \& Zimmerman, 1991).

\section{Ecology and behavior}

Based on species for fisheries, Zimmerman \& Minello (1984) and McTigue \& Zimmerman (1991) studied their behavior and how it related to ecology in the entire ecosystem. Differences between responses of Farfantepenaeus aztecus and L. setiferus led to the conclusion that both species were omnivorous; however, differences in feeding were based on the degree of carnivory or herbivory. Such differences could reflect partitioning strategies and life histories linked to temporal food availability. F. aztecus gained the specialized advantage through being more carnivorous during the spring months when $L$. setiferus are absent. Conversely, it gained an advantage through herbivory during the summer months and fed on unimportant sites and resources, suggesting that vegetable debris may have limited value for shrimp, although this finding remains inconclusive.

The relationship between the abrasive material in the gut and the ability to digest debris needs to be studied. Beseres \& Feller (2007) have shown that white shrimp are major consumers of macrobenthos, but they prefer live prey and decrease the abundance of macrobenthos through predation, both in experimental enclosures in the lab and the field. Therefore, predation takes precedence as a determinant in the seasonal cycle. White shrimp, being mobile, have densities that widely fluctuate both inter- and intra-annually; therefore, densities vary in both space and time.

Webb \& Kneib (2004) measured weight gain and movement of $L$. setiferus in the tidal stream sub-system of the Duplin River, Sapelo Island, Georgia, over two years. A total of 15,974 juveniles $(40-80 \mathrm{~mm}$ total length) were marked with an encoded microfiber and released into the shallow upper reaches of the four tidal streams and marshes. Such a habitat can achieve a balance between adequate habitat (space) at low tide, which increases residence time and the density of juveniles, thereby providing sufficient intertidal forage habitat and a predatory refuge at high tide to promote high weight gain and survival of juveniles. The study provided spatially explicit information on growth rates 
and the degree of movement within nursery grounds, as well as the initial steps needed to meet the challenge of maintaining a quality nursery for sustainable shrimp fisheries, and meeting other demands associated with human development in watershed estuaries.

\section{Reproduction}

King (1948) described the general anatomy and histology of the reproductive organs of L. setiferus and the principles of gross developmental changes in organ size, as well as color related to histological and cytological changes. Thus, a field worker, without access to a microscopy lab, could more accurately determine and record the stage of development. Such methods provide a basis for shrimp observations on reproduction, and such details are now fully known. For example, a female could potentially spawn more than once during a single breeding season, although the occurrence of this was unknown. Later studies confirmed and documented this in detail with electron microscopy (Bauer \& Cash, 1991; Chow et al., 1991). The spermatophore structure inside the male ejaculatory duct was described just after ejaculation, thereby completing previous information (Ro et al., 1990). The vas deferens work to obtain the supporting matrix, and they consolidate and orient the spermatozoid, as well as secrete some acellular components and store the developing spermatophore.

L. setiferus thelycum is open, and therefore, the fertilization of eggs is closely related to the proper transfer and adhesion of the spermatophore because the spermatozoa are transported and protected by the structure. The spermatophore is expelled from the terminal ampoule through the genital pore (Bauer \& Cash, 1991). During the expulsion process, two halves are assembled outside the body, forming a complete spermatophore, and the structures facilitate anchoring to the surface of the female's thelycum (Ro et al., 1990; Chow et al., 1991). Castille \& Lawrence (1989) evaluated $F$. aztecus and $L$. setiferus maturation using visual, histological and biochemical observations. Changes in carbohydrate, lipid and protein contents were described for the gonads and digestive glands of both males and females and the terminal portion of the male reproductive tract. Leung-Trujillo \& Lawrence (1987) tested the effects of captivity on the sperm quality of $L$. setiferus from the Gulf of Mexico. No significant decline in quality or quantity of sperm occurred until the third week of captivity. The average life of sperm decreased to $20.7 \%$ during the $5^{\text {th }}$ week in captivity. Bray et al. (1990) obtained females via hybridization of $L$. setiferus and $L$. schmitii. Their results are indicative of the phylogenetic relationships and genomic compatibility of these species. Misamore
\& Browdy (1997) evaluated the potential for spontaneous hybridization between $L$. setiferus and $L$. vannamei. Prezygotic barriers to hybridization were evaluated by utilizing quantitative analysis of the behavioral interactions that are associated with mating, artificial insemination, and a novel in vitro fertilization technique for the two species that was achieved by an upwelling of a concentrated sperm suspension under a spawning female.

Misamore \& Browdy (1996) observed the mating behavior of L. setiferus and L. vannamei and compared it with that of other species. Video analysis and visual observations indicated four sequential stages. During the chase stage, males closely followed the female, mirroring changes in the female's direction. In the probe stage, the male approaches the female ventrally and probes the region of the female with its antennae. The embrace stage is characterized by the inversion of the male and juxtaposition of its ventral surfaces with the female and the wrapping of its pereiopods around the female's shell. In the final stage, the flex stage, the male collapses its uropod, holds its abdomen slightly, and rotates perpendicular to the female's midline, forming a U-shape around the female. L. vannamei exhibited mating behavior similar to that of $L$. setiferus. However, the reduction in angle rotation and abdominal curvature during the flexion stage differed from that of L. setiferus. A generalized model of mating behavior within the Litopenaeus was proposed. This study provided a great deal of information; however, the breeding problem of the species has not yet been solved. However, there are major advances in research to find an appropriate model for captive maintenance.

Thus, from the first report of success in maturation and spawning of $L$. setiferus under lab conditions, the difficulty of males in transferring the spermatophore (Brown et al., 1979) was associated with bacterial infections. Alfaro et al. (1993) found that the genital apparatus of a male $L$. setiferus, blackens, with detrimental effects on mating when animals are kept under controlled maturation/reproduction conditions. A progressive, melanized condition of the male reproductive tract was associated with a bacterial infection. It was suggested that a progressive syndrome involving bacterial invasion, perhaps only in advanced stages or having more than one etiology, may be involved in the deterioration and blackening of the male reproductive system.

Sandifer et al. (1984) tried to implement artificial insemination. They attempted manual expulsion of spermatophores until they found that shrimp with melanized terminal ampullae generally did not expel a spermatophore following electrical stimulation. Additionally, Rosas et al. (1993) found it necessary to look 
for a better method of insemination without manipulation for $L$. setiferus because they do not regenerate quickly after electroejaculation.

Many studies have been conducted to elucidate the possible causes of the decrease in reproductive quality in males defined as a "degenerative syndrome of the male reproductive system", and characterized by a progressive decrease in the number of spermatozoa and an increase in the percentage of abnormal and dead cells (Chamberlain et al., 1983; Talbot et al., 1989). Melanization and low numbers of viable sperm cells have been common features in L. setiferus populations in the southern Gulf of Mexico (Pascual et al., 1998). In the benthic community, where the population feeds (Rosas et al., 2004), structural changes as a result of environmental disturbances caused by marine pollution and deleterious effects of high temperatures affect reproductive quality. Some hypotheses include that genotoxic damage results from an accumulation of estuarine phase pollutants or that crossbreeding increases as a consequence of population reduction because of overfishing. Pascual et al. (2003b) found differences in sperm quality between populations at the extremes of the distribution range, which results in 20 times fewer spermatozoa for populations in the southern Gulf of Mexico than those in populations in the north Atlantic region. There is an inverse relationship between temperature and reproductive activity and sperm quality.

Laboratory results showed that there is a marked effect of temperature on sperm quality of adult male $L$. setiferus. Above $26^{\circ} \mathrm{C}$, an increase in the proportion of abnormal cells was observed, indicating a reduction in the reproductive potential of the organisms. Although shrimps have a high metabolic capacity to tolerate differing experimental temperatures (Sánchez et al., 2002), the effects on sperm quality showed that their reproductive system is much more sensitive than that of energy metabolism to temperature changes. The results showed that $L$. setiferus is a species sensitive to changes in temperature, and can be an indicator species of changes caused by global warming or the El Niño phenomenon in this region of the Gulf of Mexico (Rosas et al., 2004).

Goimier et al. (2006) evaluated the effects of dietary protein levels on blood indicators of protein metabolism and immune condition (blood protein, hemocyanin, osmotic pressure and hemocyte concentrations), and reproductive capacity of preadult $L$. setiferus males $\left(F^{0}\right)$. Their results indicated that an immune reaction could occur in response to dietary protein, with excess dietary protein (DP) affecting several physiological functions, including sperm synthesis and quality. The hemocyte concentration in shrimp fed excess protein could activate an attack on sperm cells in the vas deferens, thus, provoking a loss of sperm quality. The results indicated that an optimal DP of $45 \%$ could maintain a broodstock bank of $L$. setiferus, and favor placing it in a medium with abundant protein sources of microbial origin, as in the case of intensive biofloc systems (BFT). In doing so, a better immunological condition could be stimulated, which would generate better growth and reproductive capacity.

\section{Physiology and nutrition}

Bottino et al. (1980) analyzed fatty acids (FA) of three species of shrimp from the Gulf of Mexico, white ( $L$. setiferus), brown (F. aztecus) and pink ( $F$. duorarum), periodically for one year. There were variations in FA levels compared to water temperature and a lag period of one month between a change in temperature and a corresponding change in FA composition. This slow change in shrimp FA suggests that the change occurs through the food chain and not through an endogenous adjustment. These experiments indicate that diet exerts a strong influence on body lipid composition, and in contrast, an endogenous synthesis or modification occurs to a lesser degree. Lee \& Lawrence (1985) investigated the relationships between protein level, size, apparent digestibility, digestive enzyme activities and $L$. setiferus growth. They found higher digestive enzyme activities with a diet having $22 \%$ protein and concluded this might be evidence of an adaptation to a diet that contains fewer digestible proteins.

McTigue \& Feller (1989) measured the weight of gut content (GC) relative to body weight (BW) to determine whether bowel fullness remained constant overtime, or the variations were correlated with the variation in light and tides. L. setiferus juveniles did not exhibit any clear temporal trend in the increase or decrease intestinal content relative to $\mathrm{BW}$, although the maximum content was observed in the morning. Factors responsible for the timing of the maximum are unknown but may be associated with activity level between night and day.

Rosas et al. (1995) determined the role of digestive gland (DG) in the respiratory metabolism of L. setiferus adult males as a step toward proposing a feeding scheme based on the DG activity cycle. The metabolic activity of DG was high $6 \mathrm{~h}$ after feeding, and this could indicate that assimilation started $2 \mathrm{~h}$ after food intake, peaking $6 \mathrm{~h}$ after feeding. Eight hours after feeding, the rate of $\mathrm{O}_{2}$ of DG decreased and fell to values similar to those recorded for animals subjected to $72 \mathrm{~h}$ of fasting. In other words, there was a high correlation between the rate of $\mathrm{O}_{2}$ and glucose concentration in the hemolymph, and between the rate of $\mathrm{O}_{2}$ in $\mathrm{DG}$ and glycogen concentration in DG after feeding. Gallardo et al. 
(1995) presented a basic scheme for L. setiferus larvae based on diatoms (Chaetoceros ceratosporum), flagellates (Tetraselmis chuii) and Artemia nauplii.

These authors concluded that an increase in algae concentration and Artemia indicates a pattern of development of the digestive system associated with larvae development. Such a pattern is considered to improve larvae production under controlled conditions. García et al. (1998) studied the dietary protein (DP) requirements of $L$. setiferus and $F$. duorarum postlarvae (Pls) through growth, survival and yield to conclude at $50 \%$ crude protein $(\mathrm{CP})$, despite evidence provided by studies on the dietary habits of these two species that recorded differences in the animal/ vegetable ratio of the diet with growth. Guzmán et al. (2001) investigated the effects of protein and energy content on digestive enzyme activity, and the growth and survival of $L$. setiferus Pls under controlled conditions. Dietary carbohydrates (cbh) cannot spare protein because the growth rate obtained by $L$. setiferus fed diets containing 200-300 $\mathrm{g} \mathrm{kg}^{-1}$ protein was low ( $P$ $<0.05)$.

Renaud (1986), Martínez et al. (1998) and Rosas et al. (1998, 1999) stated that dissolved oxygen (DO), unlike temperature, is an environmental regulator of shrimp metabolism. Its direct intervention provides a regulatory role in the ability to obtain energy respired through oxidative phosphorylation. A relatively small reduction in DO, $1 \mathrm{mg} \mathrm{L}^{-1}$, caused a reduction of up to $25 \%$ in energy channeled into biomass. Therefore, it is possible to infer that an abundance of $L$. setiferus in the tropical coastal environment, along with DO level, could be of great help to determine the health of the ecosystem.

Alcaraz et al. (1999a,b) measured the combined effect of ammonium, nitrite and DO on Pls consumption and reported that $L$. setiferus was more sensitive than $P$. monodon to the same pollutant. Taboada et al. (1998) assayed the effects of protein level on the growth rate, survival, pre- and postprandial $\mathrm{O}_{2}$ uptake, and ammonia excretion of $L$. setiferus juveniles. The protein appeared to be an energy substrate when in the feed (50\% crude protein [CP]) or lipid $(30 \% \mathrm{CP})$. Under these conditions, L. setiferus achieved the highest weight gain with a $30 \%$ protein diet, whereas prawns used food more efficiently (Rosas et al., 1996).

Brito et al. (2000) studied growth rate, soluble protein content, $\mathrm{O}_{2}$, ammonia excretion and digestive enzymatic activity in L. setiferus Pls with four feeding regimes, including combinations of Artemia nauplii (AN) new hatch, microparticulate commercial feed, and microalgae. Partial replacement of $\mathrm{AN}$ by an artificial diet, with or without the addition of algae for the initial Pls stage benefited growth and nutritional status of $L$. setiferus Pls. Gallardo et al. (2002) studied the adequate level of replacement of AN and microalgae by a microparticulate diet for $L$. setiferus larvae. In the absence of algae, the replacement of AN resulted in slow development with lower resistance to salinity and reduced growth and survival relative to that of algae-fed larvae.

Brito et al. (2004) quantified the amount of energy channeled for growth $(\mathrm{P})$, maintenance $(\mathrm{R})$, excretion $(\mathrm{U})$ and exuvia $(\mathrm{Ev})$ in six dietary treatments during the initial development of $L$. setiferus Pls and $L$. vannamei tested at $28^{\circ} \mathrm{C}$ and salinity of 35 . The results showed some divergence between these two species during the early Pls stages, but only when animals were in a poor physiological condition because of an inefficient diet. NA, which was partially replaced by a commercial microparticulate diet plus an algae supplement, was integrated with a high-quality diet for both species, thereby producing high-growth efficiency.

Arena et al. (2007) studied the effects of different levels of carbohydrates (cbh) and CP (23cbh-35CP, 12 cbh-45CP and 55CP-0 cbh) on the growth rate and $\alpha$ amylase and phenotypic expression in L. setiferus. The specific $\alpha$-amylase activity was inversely proportional to cbh concentration in diets, which indicated a proteininducing effect of the diet. Phenotypic expression, measured by allelic frequency, showed that different alleles were affected by DP, wherein the alleles were reduced according to the protein level. Alleles b and $c$ showed an increase in expression based on protein concentration, which demonstrated that these alleles were responsible for increased amylase activity when fed high levels of DP. The modulating role of dietary components in enzymatic activity has been previously discussed (Lovett \& Felder, 1990).

Various investigations showed some usefulness of blood parameters as tools to monitor the physiological conditions of wild and cultured shrimp exposed to diverse environmental conditions. Sánchez et al. (2001) observed that a change in water temperature between 27 and $30^{\circ} \mathrm{C}$ produced variation in the levels of protein, lactate, glucose, triglycerides, cholesterol and the immune response in wild adults of $L$. setiferus. Under captive conditions, protein, triglyceride and cholesterol levels were lower than those observed in wild-caught animals (Smith et al., 2003).

The levels of hemocyanin (OxyHc), blood protein, glucose, triacylglycerols, cholesterol and lactate in juvenile $L$. setiferus and $L$. vanname $i$ were determined to set a baseline for functional nutritional status under experimental or cultivated conditions in tanks simulating commercial conditions (Pascual et al., 2003a). Food quality was the factor that controlled the levels of metabolites in blood, suggesting that these parameters 
determine whether a wild population is well-nourished or under pressure, and can be associated with some severe environmental disturbances (Rosas et al., 2001, 2002).

Rosas et al. (2002) showed that cultured shrimp are well adapted for the use of protein as a source of energy and for growth to maintain osmotic pressure and produce glycogen and glucose by glycogen. Additionally, the immune system, with a strong protein base, depended significantly on protein metabolism (VargasAlbores \& Yepiz-Plascencia, 2000). It is well documented that $L$. setiferus juveniles are subject to sudden changes in salinity in the coastal lagoons where they live, but are also exposed to daily variations in temperature or DO (Rosas et al., 1997). Under such conditions, juveniles need to adjust osmotic pressure as a result of being in a more diluted environment. In the process of physiological adjustment at low salinity, shrimp will use a pool of free amino acids to reduce the increase cell volume caused by water intake to reduce protein concentration in the hemolymph (Rosas et al., 2001).

\section{Aquaculture}

In the 1990s, because of the information generated, interest in the cultivation of shrimp under controlled conditions began. Thus, a growing concern about viral diseases and the severe difficulties experienced by shrimp breeders in South Carolina trying to obtain $L$. vannamei Pls free from infectious hypodermal hematopoietic necrosis virus (IHHNv) provoked another assessment of the potential for the culture of the native L. setiferus (Sandifer et al., 1993). Parker \& Holcomb (1973) and Parker et al. (1974) first showed that $L$. setiferus was the best native shrimp species for aquaculture. However, Sandifer et al. (1993) demonstrated that the performance of $L$. vannamei was superior to that of $L$. setiferus in semi-intensive ponds.

Thus, after the first experiments, Waddell Mariculture Center from the Mariculture Research and Development Center conducted cycles of cultivation in 1985-1989. In 1985, nurseries of 0.1 and 0.25 ha stocked with L. setiferus were obtained from the Continental Fisheries Hatchery Ltd., Panama City. Three tanks, $0.1,0.25$ and 0.5 ha, were stocked with $L$. vannamei Pls from the Amorient Aquafarm larviculture in Hawaii that were certified free of pathogens. $L$. vannamei and L. setiferus were stocked with Pls 7-9 at an initial density of $12 \mathrm{~m}^{-2}$ for 147 days. In the 1989 experiment, $L$. setiferus Pls produced at the Waddell Mariculture Center from captive-breeders and South Carolina wild stock were stocked at two densities, 40 and $60 \mathrm{~m}^{-2}$, in 0.1 ha nurseries. Identical nurseries were stocked with $L$. vannamei Pls from a private hatchery in Costa Rica at $60 \mathrm{~m}^{-2}$ for 145 days.

The 1985 yield for L. setiferus was slightly higher than that of previously high levels from intensive farms. The 1989 experiment showed for the first time that it was feasible to intensively culture $L$. setiferus and produce the highest yield $\left(5-8 \mathrm{t} \mathrm{ha}^{-1} \mathrm{crop}^{-1}\right)$ ever achieved with the species. Overall, survival and yield levels with $L$. setiferus fell within the range of previous intensive culture results with $L$. vannamei at similar population densities. However, L. setiferus was $2 \mathrm{~g}$ lighter than $L$. vannamei at harvest. These data reinforced the findings of McKee et al. (1989) and Browdy et al. (1991) with L. vannamei. They showed better growth and yield for $L$. vannamei than $L$. setiferus and concluded that South Carolina should preferentially culture $L$. vanname $i$.

However, it appeared that nurseries provided a suitable environment for the "normal" growth of $L$. setiferus, even at densities that were many times higher than those found in the wild. However, the maximum growth rate recorded for this species in the wild was not reached in the cultures. Sandifer et al. (1993) found that the main disadvantage was the low growth rate for $L$. setiferus, and no commercial hatchery was interested in producing Pls. The advantages are that it is not a natural host for IHHNv, breeders are available in the local environment, they are native to the region, and there are no problems with physical and chemical characteristics.

The Pls supply for L. setiferus had limited commercial value for at least several years. Additional research on nutrient requirements, population density effects on growth, as well as necessary changes in nursery management procedures had to be evaluated for $L$. setiferus to be an alternative species for aquaculture. Williams et al. (1996) tested different stocking densities in a recirculation system with $L$. vanname $i$ and $L$. setiferus. The growth rate of $L$. setiferus was lower than that of $L$. vannamei. L. setiferus showed a highdensity tolerance similar to that of $L$. vannamei; therefore, it may be fit for density-intensive growth. Depressed growth rates of $L$. setiferus appeared independent of stocking density or water quality, but their cause must be solved to achieve growth rates similar to that of L. vannamei.

A few years later, and with a growing interest in live or frozen bait for recreational fisheries, interest in intensive cultivation of $L$. setiferus returned, although economic profitability studies had not yet been conducted. Samocha et al. (1998) conducted a study to evaluate whether intensive shrimp farming developed for $L$. vannamei could be used successfully to produce L. setiferus of bait size in outdoors nurseries of southern Texas. The study evaluated the effects of two highstocking densities, two feeding types and two water circulation systems on growth and survival after 120 
days to determine whether the economic viability of the L. setiferus bait facility in Texas could be improved (Samocha et al., 1998). Shrimp bait size, average weight 5-7 g, was reached in 90 to 120 days of culture. Mean survival value in the four nurseries stocked at 700 Pls $6 \mathrm{~m}^{-2}$ was $58.1 \%$ ("high exchange"), whereas the mean survival value of four ponds stored at 350 Pls 6 $\mathrm{m}^{-2}$ ("low exchange") was $65 \%$. The difference in survival between "high exchange" and "low exchange" was $6 \%$. A negative value reduced performance, high density negatively affected survival, and there was a $10 \%$ survival in nurseries fed a high protein ratio. Samocha et al. (1998) concluded that $L$. setiferus Pls stocked at $700 \mathrm{Pls} \mathrm{m}^{-2}$ in a small outdoor nursery, for 6 $\mathrm{g}$ bait in 94 days, with a $75 \%$ survival led an extrapolated yield of $31 \mathrm{~m}$ in ha ${ }^{-1}$ with a commercial ration. The study also suggested that production nurseries should be equipped with a $1 \mathrm{hp}$ paddle aerator to support high biomass, and a similar installation of a bottom aeration grid, air transport pump and a nursery divider in the center.

Preliminary economic analysis and effect testing suggested that, under the conditions of the study, feed had the most significant effect on survival, growth and profitability. Efforts to develop a more complete and balanced feed for L. setiferus may be the technological advancements needed to make shrimp bait production more economically viable (Samocha et al., 1998).

Palomino et al. (2001) evaluated the effects of stocking density and water exchange on the growth rate, survival and performance of $L$. setiferus Pls under laboratory conditions. The experiment was conducted with Pls ( $\mathrm{PL}_{10}$ to $\left.\mathrm{PL}_{40}\right)$ at 50, 150, 250 and 350 shrimp $\mathrm{m}^{-2}$, and several water exchanges per day $(0,6,12$ and $18 \%$ ). The maximum growth rate was obtained for shrimp with a $12 \%$ water exchange per day at all densities. There was a reduction in maximum growth rate with density, with the highest values for shrimp stocked at 50 and 150 shrimp m ${ }^{-2}$ (mean value $0.53 \mathrm{mg}$ $\left.\mathrm{d}^{-1}\right)$ and the lowest values for shrimp stocked at 350 shrimp $\mathrm{m}^{-2}\left(0.24 \mathrm{mg} \mathrm{d}^{-1}\right)$. Thus, this study reported the lowest values for growth rate.

Valenzuela et al. (2002) placed L. setiferus at a stocking density of $40 \mathrm{Pls} \mathrm{m}^{-2}$ in $20,000 \mathrm{~L}$ tanks in marine and low-salinity water. There was a slight tendency for higher growth in low-salinity water tanks during the first 75 days. However, at the end of the experiment (116 days), the mean final wet weight of 15 $\mathrm{g}$ was obtained for the marine water tanks, whereas a lower mean final wet weight of $10 \mathrm{~g}$ in the low-salinity water tanks. There was a growth rate of $0.92 \mathrm{~g} \mathrm{week}^{-1}$ in marine water and $0.61 \mathrm{~g} \mathrm{week}^{-1}$ at low salinity. Improving culture conditions and providing live food inside the nursery (green water), may aid in the success in the cultivation of this species. A recent review of new shrimp culture technologies has been conducted, and it was suggested to use these technologies for the culture of shrimp as live bait, for L. setiferus, F. duorarum and $F$. aztecus. These technologies included the use of mature wild females and spawning in the laboratory, intensive nursery systems without water exchanges, adequate rations and all possible biosecurity measures (Gandy, 2007).

Perez-Velazquez et al. (2013) studied salinity in a range of 1-48 $\mathrm{g} \mathrm{L}^{-1}$ on the performance (weight gain and survival) of $L$. vannamei and $L$. setiferus at 20,24 or $28^{\circ} \mathrm{C}$. Low growth and survival of $L$. vannamei were noted after $21-28$ days at 2 and $4 \mathrm{~g} \mathrm{~L}^{-1}$ and $20^{\circ} \mathrm{C} ; 8$ and $32 \mathrm{~g} \mathrm{~L} \mathrm{~L}^{-1}$ significantly increased survival at this temperature, which indicated that low temperature was critical for survival at low salinity. A substantial improvement in the growth rate of L. vannamei at $24^{\circ} \mathrm{C}$ was not optimal compared to the growth rate at $28^{\circ} \mathrm{C}$. Regardless of salinity, high survival rates at 24 and $28^{\circ} \mathrm{C}$ allowed for a variable growth rate.

Unlike L. vannamei, L. setiferus reared for 28 days at $24^{\circ} \mathrm{C}$ showed better growth performance at $8 \mathrm{~g} \mathrm{~L}^{-1}$ compared to 2, 16 and $32 \mathrm{~g} \mathrm{~L}^{-1}$. Under similar experimental conditions, L. setiferus had considerably lower weight gain and survival than $L$. vannamei based on previous literature (between 0.35 and $0.45 \mathrm{~g} \mathrm{week}^{-1}$ ).

\section{Perspectives}

The current situation regarding the shrimp industry poses challenges that need to be overcome. To replace fishmeal, the formulation of foods that will help to mitigate the effects of diseases, incorporate the appropriate use of natural foods, prebiotics and probiotics, reduce the use of antibiotics, and manage microbial ecology, among other factors, will be the focus of research on cultivated prawns. Research on nutrition and food will be mainly influenced by market variables, pressures on environmental policy and the availability of inputs, among other factors. Specifically, studies that have been conducted with this species have generated important advances in the production of larvae with an already established and proven scheme, especially where there are problems to avoid, such as the deterioration of the captive males, which limits reproduction, and the intensive production of good quality Pls of this species. The formulation of special feeds for different shrimp species is a basic necessity. However, perhaps the best option is to provide shrimps with an environment rich in microorganisms that provide excellent water quality and generate ecological succession to maintain heterotrophic bacteria and invertebrates up to nematodes. Thus, improving nutrition and immunology status, such as work carried 
out with biofloc, should continue until optimal conditions for survival and growth are determined.

\section{ACKNOWLEDGMENTS}

The authors thank the government of Brazil for financial support through the Program of Students in Agreement for Post-Graduation (PEC-PG), the Coordination for the Improvement of Higher-Level Personnel (Brazil-CAPES) Finance Code 001, and the Project DGAPA-UNAM No. 221316-3. W.J. Wasielesky Jr. is a research fellow of CNPq-Brazil.

\section{REFERENCES}

Alcaraz, G., Chiappa-Carrara, X., Espinoza, V. \& Vanegas, C. 1999a. Acute toxicity of ammonia and nitrite to white shrimp Penaeus setiferus postlarvae. Journal of the World Aquaculture Society, 30: 90-97.

Alcaraz, G., Espinoza, V., Vanegas, C. \& ChiappaCarrara, X. 1999b. Acute effect of ammonia and nitrite on respiration of Penaeus setiferus post larvae under different oxygen levels. Journal of the World Aquaculture Society, 30: 98-106.

Alfaro, J., Lawrence, A.L. \& Lewis, D. 1993. Interaction of bacteria and male reproductive system blackening disease of captive. Aquaculture, 117: 1-8.

Arena, L., García, F., Regalado, I., Sosa, V., Cuzon, G., Gaxiola, G. \& Rosas, C. 2007. Effect of diets with different carbohydrate concentrations in the growth, the phenotypic expression, and specific activity of alpha-amylase in shrimp Penaeus (Litopenaeus) setiferus. Aquaculture, 272(1): 238-321. doi: 10. 1016j.aquaculture.2007.07.024

Arenas-Fuentes, V. \& Jiménez-Badillo, L. 2004. La pesca en el Golfo de México. Hacia mayores biomasas en explotación. In: Caso, M., Pisanty, I. \& Ezcurra, E. (Eds.). Diagnóstico ambiental del Golfo de México. Secretaría de Medio Ambiente y Recursos Naturales, Instituto Nacional de Ecología, Ciudad de México, pp. 755-769.

Baker, R., Fujiwara, M. \& Minello, T. 2014. Juvenile growth and mortality effects on white shrimp Litopenaeus setiferus population dynamics in the northern Gulf of Mexico. Fisheries Research, 155: 7482.

Bauer, R.T. \& Cash, C.E. 1991. Spermatophore structure and anatomy of the ejaculatory duct in Penaeus setiferus, $P$. duorarum, and $P$. aztecus (Crustacea: Decapoda): homologies and functional significance. Transactions of the American Microscopical Society, 110(2): 144-162.

Beseres, J.J. \& Feller, R.J. 2007. Importance of predation by white shrimp Litopenaeus setiferus on estuarine subtidal macrobenthos. Journal of Experimental Marine Biology and Ecology, 344: 193-205.

Bottino, N.R., Gennity, J., Lilly, M.L., Simmons, E. \& Finne, G. 1980. Seasonal and nutritional effects on the fatty acids of three species of shrimp, Penaeus setiferus, $P$. aztecus, and $P$. duorarum. Aquaculture, 19: 139-148.

Bray, W.A., Lawrence, A.L., Lester, J. \& Smith, L.L. 1990. Hybridization of Penaeus setiferus (Linnaeus, 1767) and Penaeus schmitti Burkenroad, 1936 (Decapoda). Journal of Crustacean Biology, 10(2): 278-283. doi: 10.1163/193724090X00087

Brito, R., Chimal, M.E., Gelabert, R., Gaxiola, G. \& Rosas, C. 2000. Growth, metabolic rate, and digestive enzyme activity in the white shrimp Litopenaeus setiferus early postlarvae fed different diets. Journal of Experimental Marine Biology and Ecology, 255: 2136.

Brito, R., Chimal, M.E., Gelabert, R., Gaxiola, G. \& Rosas, C. 2004. Effect of artificial and natural diets on energy allocation in Litopenaeus setiferus (Linnaeus, 1767) and Litopenaeus vannamei (Boone, 1931) early postlarvae. Aquaculture, 237: 517-531.

Browdy, C.L., Stokes, A.D., Hopkins, J.S. \& Sandifer, P.A. 1991. Evaluation of intensive pond mono- and polyculture of Penaeus setiferus and $P$. vannamei in South Carolina. Journal of the World Aquaculture Society, 22(3): 16-26.

Brown Jr., A., Macvey, J., Middleditch, B.S. \& Lawrence, A.L. 1979. Maturation of white shrimp (Penaeus setiferus) in captivity. World Mariculture Society, 10: 435-444.

Castille, F.L. \& Lawrence, A.L. 1989 Relationship between maturation and biochemical composition of the gonads and digestive glands of the shrimps Penaeus aztecus Ives and Penaeus setiferus (L.). Journal of Crustacean Biology, 9(2): 202-211. doi: 10.1163/193724089X 00025

Chamberlain, G., Johnson, S. \& Lewis, D. 1983. Swelling and melanization of the male reproductive system of captive adult penaeid shrimp. Journal of the World Mariculture Society, 14: 135-136.

Chow, S., Browdy, C.L. \& Sandifer, P.A. 1993. Timing of ovulation in the Atlantic white shrimp Penaeus setiferus (Linnaeus, 1767) (Decapoda, Penaeidae). Crustaceana, 64: 242-248.

Chow, S., Dougherty, M.M., Dougherty, W.J. \& Sandifer, P.A. 1991. Spermatophore formation in the white shrimp Penaeus setiferus and $P$. vannamei. Journal of Crustacean Biology, 11(2): 201-216. doi: 10.1163/ 193724091X00022 
Diop, H., Keithly Jr., W.R., Kazmierczak Jr., R.F. \& Shawb, R.F. 2007. Predicting the abundance of white shrimp (Litopenaeus setiferus) from environmental parameters and previous life stages. Fisheries Research, 86: 31-41.

Food and Agriculture Organization (FAO). 1980. Shrimps and prawns of the world. An annotated catalog of species of interest to fisheries. Species catalog. FAO Fisheries Synopsis, 125(1): 271 pp.

Flores-Coto, C., Becerril-Martínez, J.A., Zavala-García, F., Gracia, A. \& Burke, J.S. 2010. Shrimp post-larvae immigration during the high current velocity period of the flood tide in the southern Gulf of Mexico. Hidrobiológica, 20(1): 1-12.

Fuller, P.L., Knott, D.M., Kingsley-Smith, P.R., Morris, J.A., Buckel, C.A., Hunter, M.E. \& Hartman, L.D. 2014. Invasion of Asian tiger shrimp, Penaeus monodon Fabricius, 1798, in the western north Atlantic and the Gulf of Mexico. Aquatic Invasions, 9: 59-70. doi: 10.3391/ai.2014.9.1.05.

Gallardo, P.P., Alfonso, E., Gaxiola, G., Soto, L.A. \& Rosas, C. 1995. Feeding schedule of Penaeus setiferus larvae based in diatoms (Chaetoceros ceratosporum), flagellates (Tetraselmis chuii) and Artemia nauplii. Aquaculture, 131: 239-253.

Gallardo, P.P., Pedroza-Islas, R., García-Galano, T., Pascual, C., Rosas, C., Sánchez, A. \& Gaxiola, G. 2002. Replacement of live food with a micro bound diet in feeding Litopenaeus setiferus (Burkenroad) larvae. Aquaculture Research, 33: 681-691. doi: 10.1046/j.1365-2109.2002.00705.x

Gandy, R.L. 2007. Bait shrimp culture. United States Department of Agriculture, Cooperative State Research, Education, and Extension Service. Southern Regional Aquaculture Center, 1201: 5 pp.

García, G.T., Pedroza, R., Soto, L.A., López, N. \& Rosas, C. 1998. Influencia de las proteínas dietéticas sobre el crecimiento, la sobrevivencia y el rendimiento de las post-larvas del camarón blanco (Penaeus setiferus) y del camarón rosado ( $P$. duorarum) del Golfo de México. Revista AquaTic, 2: 10 pp.

Gaxiola, G., Arena, L., Aragón, H., Emerenciano, M., Maldonado, J.C., Concha, W., Chiappa, X., Gamboa, J. \& Cuzón, G. 2008. Some aspects of feeding and nutrition of native Farfantepenaeus duorarum. In: Cruz-Suárez, L.E., Ricque-Marie, D., Tapia-Salazar, M., Nieto-López, M.G., Villareal-Cavazos, D.A., Lazo, J.P. \& Viana, M.T. (Eds.). IX Simposio Internacional de Nutrición Acuícola, 24-27 noviembre. Avances en Nutrición Acuícola, Universidad Autónoma de Nuevo León, Monterrey, pp. 410-420.

Gierloff-Emdem, H.G. 1977. Laguna de Terminos and Campeche Bay, Gulf of Mexico: water mass interaction lagoonal oceanic visible due to sediment landed waters. In: De Gruyter, W. (Ed.). Orbital remote sensing of coastal and offshore environments, a manual of interpretation. De Gruyter, Berlin, pp. 7789.

Goimier, Y., Pascual, C., Sánchez, A., Gaxiola, G., Sánchez, A. \& Rosas, C. 2006. The relation between the reproductive, physiological, and immunological condition of Litopenaeus setiferus pre-adult males fed different dietary protein levels (Crustacea; Penaeidae). Animal Reproduction Science, 92: 193-208.

Gracia, A. 1991. Spawning stock-recruitment relationship of white shrimp in the southwestern Gulf of Mexico. Transactions of the American Fisheries Society, 120: 319-327.

Gracia, A. 1996. White shrimp (Penaeus setiferus) recruitment overfishing. Marine and Freshwater Research, 47: 59-65.

Gracia, A. 1999. Shrimp fisheries in the southern Gulf of Mexico. Present and future management alternatives. In: Kumpf, H., Steidinger, D. \& Sherman, K. (Eds.). The Gulf of Mexico large marine ecosystem: assessment, sustainability, and management. Blackwell Science, Berlin, pp. 205-234.

Gracia, A. 2004. Aprovechamiento y conservación del recurso camarón. In: Caso, M., Pisanty, I. \& Ezcurra, E. (Eds.). Diagnóstico ambiental del Golfo de México. Secretaría de Medio Ambiente y Recursos Naturales, Instituto Nacional de Ecología, Ciudad de México, pp. 713-723.

Gracia, A. \& Soto, L.A. 1990. Population study of the penaeid shrimp of Términos Lagoon, Campeche, Mexico. Anales del Instituto de Ciencias del Mar y Limnología, 17(2): 241-255.

Guzman, C., Gaxiola, G., Rosas, C. \& Torre-Blanco, A. 2001. The effect of dietary protein and total energy content on digestive enzyme activities, growth, and survival of Litopenaeus setiferus (Linnaeus, 1767) postlarvae. Aquaculture Nutrition, 7: 113-122.

King, J.E. 1948. A study of the reproductive organs of the common marine shrimp Penaeus setiferus (Linnaeus). Biological Bulletin, 94(3): 244-262.

Lee, P. \& Lawrence, A.L. 1985. Effects of diet and size on growth, fed digestibility, and digestive enzyme activities of the marine shrimp Penaeus setiferus Linnaeus. Journal of the World Aquaculture Society, 16: $275-287$.

Leung-Trujillo, J.R. \& Lawrence, A.L. 1987. Observations on the decline in sperm quality of Penaeus setiferus under laboratory conditions. Aquaculture, 65(3-4): 363-370.

Lovett, D.L. \& Felder, D.L. 1990. Ontogeny of kinematics in the gut of the white shrimp Penaeus setiferus (Decapoda: Penaeidae). Journal of Crustacean Biology, 10(1): 53-68. doi: 10.1163/193724090X00 249 
Martínez, E., Aguilar, M., Trejo, L., Hernández, I., DíazIglesia, E., Soto, L.A., Sanchez, A. \& Rosas, C. 1998. Lethal low dissolved oxygen concentrations for postlarvae and early juvenile Penaeus setiferus at different salinities and $\mathrm{pH}$. Journal of the World Aquaculture Society, 29: 221-229.

McTiegue, T.A. \& Feller, R.J. 1989. Feeding of juvenile white shrimp Penaeus setiferus: periodic or continuous? Marine Ecology Progress Series, 52: 221233.

McTiegue, T.A. \& Zimmerman, R.J. 1991. Carnivory vs. herbivory in juvenile Penaeus setiferus (Linnaeus) and Penaeus aztecus (Ives). Journal of Experimental Marine Biology and Ecology, 151: 1-16.

McKee, D.A., Lawrence, A.L. \& Griffin, W.L. 1989. Stocking strategies and investment analysis for producing Penaeus setiferus as a live bait shrimp on the Texas Gulf coast. Journal of the World Aquaculture Society, 20(2): 72-80.

Minello, T.J. \& Zimmerman, R.J. 1991. The role of estuarine habitats in regulating growth and survival of juvenile penaeid shrimp. In: Deloach, P.F., Dougherty, W.J. \& Davidson, M.A. (Eds.). Frontiers of shrimp research. Elsevier, Amsterdam, pp. 1-16.

Misamore, M.J. \& Browdy, C.L. 1996. Mating behavior in the white shrimps Penaeus setiferus and $P$. vannamei: a generalized model for mating in Penaeus spp. Journal of Crustacean Biology, 16: 61-70.

Misamore, M.J. \& Browdy, C.L. 1997. Evaluating hybridization potential between Penaeus setiferus and Penaeus vannamei through natural mating, artificial insemination, and in vitro fertilization. Aquaculture, 150: $1-10$.

Palomino, A.G., Contreras, F., Sanchez, A. \& Rosas, C. 2001. Density and water exchange dependent growth and survival of Litopenaeus setiferus postlarvae. Journal of the World Aquaculture Society, 32: 27-36.

Parker, J.C. \& Holcomb Jr., H.W. 1973. Growth and production of brown and white shrimp (Penaeus aztecus and $P$. setiferus) from experimental ponds in Brazoria and Orange Counties. Journal of the World Aquaculture Society, 4(1-4): 215-234.

Parker, J.C., Conte, F.S., McGrath, W.S. \& Miller, B.W. 1974. An intensive culture system for penaeid shrimp. Proceedings of the World Mariculture Society, 5: 6579.

Pascual, C., Gaxiola, G. \& Rosas, C. 2003a. Blood metabolites and hemocyanin of the white shrimp Litopenaeus vannamei: the effect of culture conditions and a comparison with other crustacean species. Marine Biology, 142: 735-745.

Pascual, C., Sanchez, A., Vargas-Albores, F., LeMoullac, G. \& Rosas, C. 2003b. Hemolymph metabolic variables and immune response in Litopenaeus setiferus adult males: the effect of an extreme temperature. Aquaculture, 218: 637-650.

Pascual, C., Valera, E., Regis, R., Gaxiola, G., Sanchez, A., Ramos, L., Soto, L.A. \& Rosas, C. 1998. Effect of temperature on reproductive tract condition of Penaeus setiferus adult males. Journal of the World Aquaculture Society, 29: 477-484.

Perez-Velazquez, M., González-Félix, M.L., Davis, D.A., Roy, L.A. \& Zhu, X. 2013. Studies of the thermal and hyaline influences on growth and survival of Litopenaeus vannamei and Litopenaeus setiferus. Journal of the World Aquaculture Society, 44: 229238.

Renaud, M.L. 1986. Detecting and avoiding oxygendeficient seawater by brown shrimp Penaeus aztecus (Ives) and white shrimp $P$. setiferus (Linnaeus). Journal of Experimental Marine Biology and Ecology, 98: 283-292.

Ro, S., Talbot, P., Leung-Trujillo, J. \& Lawrence, A.L. 1990. Structure and function of the vas deferens in the shrimp Penaeus setiferus segments 1-3. Journal of Crustacean Biology, 10(3): 455-468. doi: 10.2307/ 1548335

Rosas, C., Ocampo, L., Gaxiola, G., Sánchez, A. \& Soto, L.A. 1999. Effect of salinity on survival, growth, and oxygen consumption of postlarvae (PL10-PL21) of Penaeus setiferus. Journal of Crustacean Biology, 19(2): 244-251.

Rosas, C., Bolongaro-Crevenna, A., Sanchez, A., Gaxiola, G., Soto, L.A. \& Escobar, E. 1995. Role of the digestive gland in the energetic metabolism of Penaeus setiferus. Biological Bulletin, 189: 168-174.

Rosas, C., Cuzon, G., Taboada, G., Pascual, C., Gaxiola, G. \& Van Wormhoudt, A. 2001. Effect of dietary protein and energy levels $(\mathrm{P} / \mathrm{E})$ on growth, oxygen consumption, hemolymph, and digestive gland carbohydrates, nitrogen excretion, and osmotic pressure of Litopenaeus vannamei and L. setiferus juveniles (Crustacea, Decapoda; Penaeidae). Aquaculture Research, 32: 1-20.

Rosas, C., Martínez, E., Gaxiola, G., Brito, R., DíazIglesia, E. \& Soto, L.A. 1998. Effect of dissolved oxygen on the energy balance and survival of Penaeus setiferus juveniles. Marine Ecology Progress Series, 174: 67-75.

Rosas, C., Sánchez, A., Chimal, M.A.E., Saldania, G., Ramos, L. \& Soto, L.A. 1993. The effect of electrical stimulation on spermatophore regeneration in white shrimp Penaeus setiferus. Aquatic Living Resources, 6: 139-144.

Rosas, C., Sánchez, A., Díaz, E., Soto, L.A., Gaxiola, G. \& Brito, R. 1996. Effect of dietary protein level on apparent heat increment and postprandial nitrogen 
excretion of Penaeus setiferus, $P$. schmitti, $P$. duorarum, and $P$. notialis postlarvae. Journal of the World Aquaculture Society, 27: 92-102.

Rosas, C., Sánchez, A., Díaz-Iglesia, E., Brito, R., Martinez, E. \& Soto, L.A. 1997. Critical dissolved oxygen level to Penaeus setiferus and Penaeus schmitti postlarvae ( $\left.\mathrm{PL}_{10-18}\right)$ exposed to salinity changes. Aquaculture, 152: 259-272.

Rosas, C., Cuzon, G., Gaxiola, G., Pascual, C., Taboada, G., Arena, L. \& Van Wormhoudt, A. 2002. An energetic and conceptual model of the physiological role of dietary carbohydrates and salinity on Litopenaeus vannamei juveniles. Journal of Experimental Marine Biology and Ecology, 268: 47-67.

Rosas, C., Coloper, E.L., Pascual, C., Brito, R., Gelabert, R., Moreno, T., Miranda, G. \& Sánchez, A. 2004. La condición reproductiva del camarón blanco Litopenaeus setiferus (Crustacea; Penaeidae): evidencias de deterioro ambiental en el sur del Golfo de México. In: Caso, M., Pisanty, I. \& Ezcurra, E. (Eds.). Diagnóstico ambiental del Golfo de México. Secretaría de Medio Ambiente y Recursos Naturales, Instituto Nacional de Ecología, Ciudad de México, pp. 789-819.

Samocha, T.M., Burkott, B.J., Lawrence, A.L., Juan, Y.S., Jones, E.R. \& McKee, D.A. 1998. Management strategies for the production of the Atlantic white shrimp Penaeus setiferus as bait shrimp in outdoor ponds. Journal of the World Aquaculture Society, 29: 211-220.

Sánchez, A., Pascual, C., Sánchez, A., Vargas-Albores, F., Le Moulla, G. \& Rosas, C. 2001. Hemolymph metabolic variables and immune response in Litopenaeus setiferus adult males: the effect of acclimation. Aquaculture, 198: 13-28.

Sánchez, A., Pascual, C., Sánchez, A., Vargas-Albores, F., Le Moullac, G. \& Rosas, C. 2002. Acclimation of adult males of Litopenaeus setiferus exposed at $27^{\circ} \mathrm{C}$ and $31^{\circ} \mathrm{C}$ : bioenergetic balance. In: Escobar-Briones, E.G. \& Alvarez, F. (Eds.). Modern approaches to the study of crustacea. Kluwer Academic Press, New York, pp. 45-52.

Sandifer, P.A., Hopkins, J.S., Stokes, A.D. \& Browdy, C.L. 1993. Preliminary comparisons of the native Penaeus setiferus and Pacific P. vannamei white shrimp for pond culture in South Carolina, USA. Journal of the World Aquaculture Society, 24: 295303.

Sandifer, P.A., Lawrence, A.L., Harris, S.G., Chamberlain, G.W., Stokes, A.D. \& Bray, W.A. 1984. Electrical stimulation of spermatophore expulsion in marine shrimp, Penaeus spp. Aquaculture, 41: 181187.
Smith, V.J., Brown, J.H. \& Hauton, C. 2003. Immunostimulation in crustaceans: does it protect against infection? Fish and Shellfish Immunology, 15: 71-90.

Taboada, G., Gaxiola, G., García, T., Pedroza, R., Sánchez, A., Soto, L.A. \& Rosas, C. 1998. Oxygen consumption and ammonia excretion related to protein requirements for growth of shrimp Penaeus setiferus. Aquaculture Research, 29: 823-833.

Talbot, P., Howard, D., Leung-Trujillo, J., Lee, T., Li, WY., Ro, H. \& Lawrence, A.L. 1989. Characterization of male reproductive tract degenerative syndrome in captive penaeid shrimp (Penaeus setiferus). Aquaculture, 78: 365-377.

Valenzuela, J.M., Sánchez, Z.A., Rosas, V.C., Suárez, B.J. \& Arévalo, C.M. 2002. El uso de estanques de manto freático para la acuacultura. Memorias del II Congreso Nacional de la Asociación Mexicana de Limnología, 23 al 25 de octubre del 2002. Facultad de Ciencias, Universidad Nacional Autónoma de México, México D.F., pp. 1-9.

Vargas-Albores, F. \& Yepiz-Plascencia, G. 2000. Betaglucan binding protein and its role in shrimp immune response. Aquaculture, 191: 13-21.

Wakida-Kusunoki, A.T., Amador-del Angel, L.E., Carrillo-Alejandro, P. \& Quiroga-Brahms, C. 2011. Presence of Pacific white shrimp Litopenaeus vannamei (Boone, 1931) in the southern Gulf of Mexico. Aquatic Invasions, 6(1): 139-142. doi: 10.3391/ai.2011.6.S1.031

Wakida-Kusunoki, A.T., Rojas-González, R.J., GonzálezCruz, A., Amador-del Ángel, L.E., Sánchez-Cruz, J.L. \& López-Tellez, N.A. 2013. Presence of giant tiger shrimp Penaeus monodon Fabricius, 1798 on the Mexican coast of the Gulf of Mexico. BioInvasions Records, 2: 325-328. doi: 10.3391/bir.2013.2.4.11

Webb, S. \& Kneib, R.T. 2004. Individual growth rates and movement of Litopenaeus setiferus in a tidal marsh nursery. Fishery Bulletin, 102: 376-388.

Williams, A.B. 1984. Shrimp, lobsters, and crabs of the Atlantic coast of the eastern US Maine to Florida. Smithsonian Institution Press, Washington D.C.

Williams, A.S., Davis, D.A. \& Arnold, C.R. 1996. Density-dependent growth and survival of Penaeus setiferus and Penaeus vannamei in a semiclosed recirculating system. Journal of the World Aquaculture Society, 27(1): 107-112.

Zein-Eldin, Z.P. \& Renaud, M.L. 1986. Inshore environmental effects on brown shrimp Penaeus aztecus and white shrimp P. setiferus populations in coastal waters, particularly of Texas. Marine Fisheries Review, 48: 9-19. 
Zimmerman, R.J. \& Minello, T.J. 1984. Estuaries densities of Penaeus aztecus, Penaeus setiferus, and other natant macrofauna in a Texas salt marsh. Estuaries, 7(4): 421-433. doi: 10.2307/1351623

Received: 7 March 2019; Accepted: 21 November 2019 